\title{
In-Place Oil Shale Resources in the Saline-Mineral and Saline- Leached Intervals, Parachute Creek Member of the Green River Formation, Piceance Basin, Colorado
}

A recent U.S. Geological Survey analysis of the Green River Formation of the Piceance Basin in western Colorado shows that about 920 and 352 billion barrels of oil are potentially recoverable from oil shale resources using oil-yield cutoffs of 15 and 25 gallons per ton (GPT), respectively. This represents most of the high-grade oil shale in the United States. Much of this rich oil shale is found in the dolomitic Parachute Creek Member of the Green River Formation and is associated with the saline minerals nahcolite and halite, or in the interval where these minerals have been leached by groundwater. The remaining highgrade resource is located primarily in the underlying illitic Garden Gulch Member of the Green River Formation. Of the 352 billion barrels of potentially recoverable oil resources in high-grade $(\geq 25$ GPT) oil shale, the relative proportions present in the illitic interval, non-saline $\mathbf{R}-2$ zone, saline-mineral interval, leached interval (excluding leached Mahogany zone), and Mahogany zone were $3.1,4.5,36.6,23.9$, and 29.9 percent of the total, respectively. Only 2 percent of high-grade oil shale is present in marginal areas where saline minerals were never deposited.

The U.S. Geological Survey (USGS) recently estimated total oil shale resources in the Piceance Basin of the Eocene Green River Formation in western Colorado to be approximately 1.525 trillion barrels of oil in-place, regardless of grade (Johnson and others, 2010). In an attempt to further refine this estimate, we determined that about 920 billion barrels or 60 percent of the in-place total can be generated from oil shale yielding at least 15 gallons of oil per ton of rock (GPT), and about 352 billion barrels or 23 percent of the total is associated with oil shale yielding at least 25 GPT (Mercier and others, 2010).

The Green River Formation, deposited in Eocene Lake Uinta, is subdivided into an early illitic phase, the Garden Gulch Member, which predates saline-mineral deposition in the lake (fig. 1, R-0 through L-1 oil shale zones), and a later carbonate and saline-mineral phase, the Parachute Creek Member, during which the saline minerals nahcolite and halite were deposited in offshore areas of the lake (fig. 1, R-2 zone through bed 44 interval). These two intervals are separated by a brief transitional section in the lower R-2 zone (fig. 1 and fig. 3) where illite content is greatly reduced, dolomite appears as a significant component, and saline minerals are not yet present. Saline minerals have been extensively leached by groundwater

Figure 1. Chart showing oil yield in gallons per ton and the "rich" and "Iean" oil shale zones in Green River Formation, Piceance Basin, assessed in this study (Donnell and Blair, 1970; Cashion and Donnell, 1972). On the right side, the major stratigraphic-mineralogical intervals are highlighted.

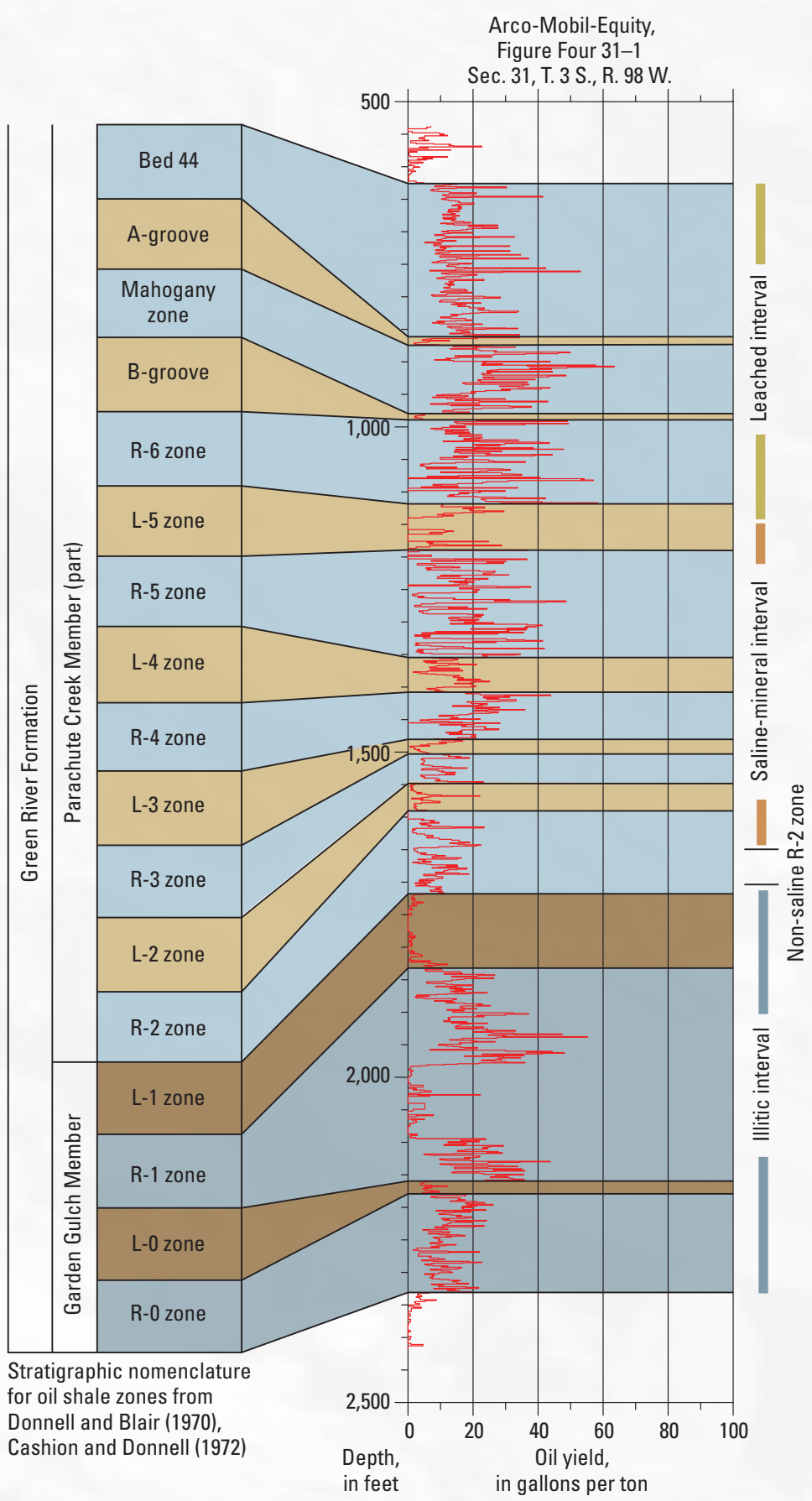

EXPLANATION

Rich oil shale zones-carbonate rich Lean oil shale zones-carbonate rich Rich oil shale zones-clay rich Lean oil shale zones-clay rich 


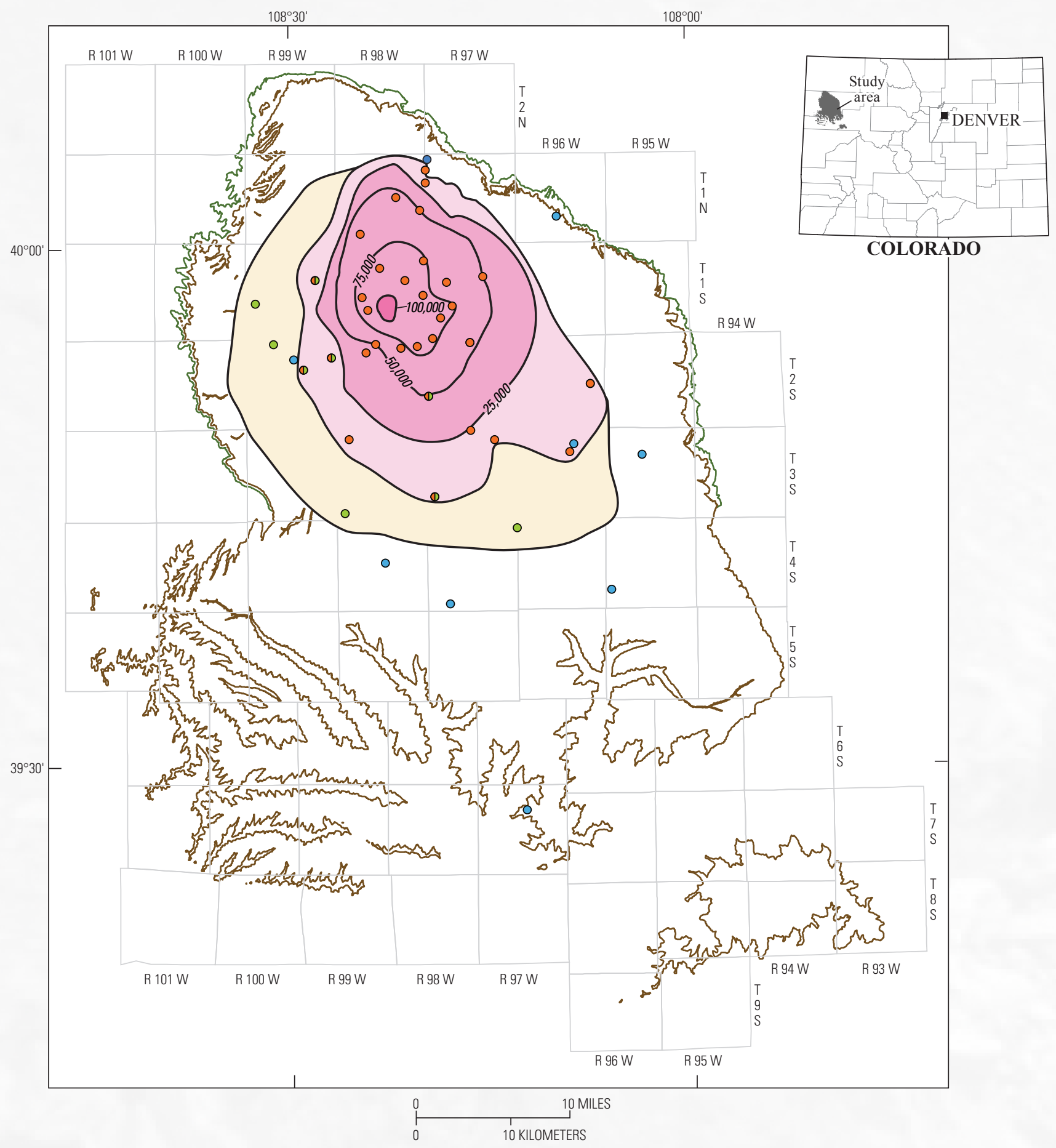

EXPLANATION

Nahcolite (short tons/acre)
\begin{tabular}{|l|l}
\hline & Nahcolite leached \\
& $<25,000$ \\
\hline \hline & $25,000-100,000$ \\
& $100,000-200,000$
\end{tabular}

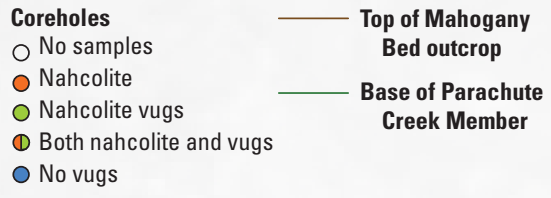

Figure 2. Distribution of in-place nahcolite resources and related features based on core analysis in the R-4 oil shale zone, Parachute Creek Member of the Green River Formation, Piceance Basin, Colorado. 


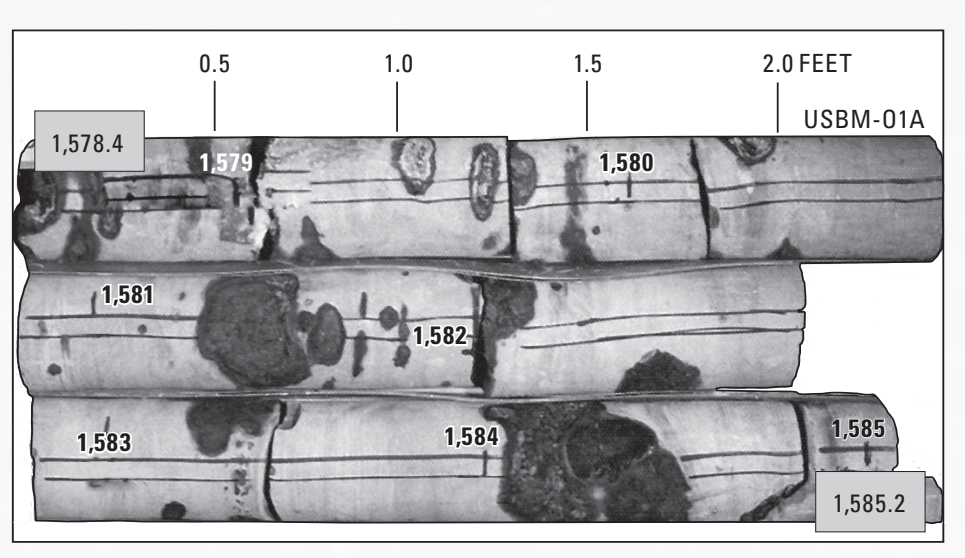

Drill core containing three forms of nahcolite associated with oil shale: coarse-white crystals, small nodules, and dark-brown aggregates. Core from the U.S. Bureau of Mines 01A (C0334) borehole (1,578.4-1,585.2 feet) and is located at the U.S. Geological Survey's Core Research Center, Denver, Colorado. Photograph from Brownfield

from shallower parts of the saline interval by relatively recent groundwater movement, producing vuggy and brecciated oil shale around the intact saline areas (figs. 2 and 3). Here, in-place oil shale resources are estimated for: (1) the Garden Gulch Member, (2) the Parachute Creck Member prior to the appearance of saline minerals, (3) the Parachute Creek Member where saline minerals are intact, (4) the Parachute Creek Member where saline minerals have been leached, and (5) the marginal oil shales from around the outer margins of the basin where saline minerals were never present. In addition, the in-place resource in the Mahogany zone and bed 44 within the leached interval of the Parachute Creek Member are estimated separately from the other leached oil shale resources due (T) The presence of nahcolte and halite in the saline-mineral in ii cial development of Green River oil shale in the Piceance BasinNahcolite is distributed widely in the basin center (see figs. 2 and 3), and it is a leasable mineral as defined by the Bureau of L and Management. Therefore, nahcolite cannot be destroyed during the development of oil shale resources. Several companies that currently hold research, development, and demonstration (RD\&D) leases on Federal lands are studying approaches to develop both nahcolite and oil shale resources using combinations of solution mining and in situ retorting technologies. A potential issue with this combination of processes arises when oil shale heating precedes nahcolite recovery. Carbon dioxide $\left(\mathrm{CO}_{2}\right)$ gas is released when nahcolite breaks down into natrite (a sodium carbonate mineral) at between 100 and $200^{\circ} \mathrm{C}\left(212-392^{\circ} \mathrm{F}\right)$ depending depth (Boak, 2011), which is significantly below oil shale retor temperatures $\left(3350^{\circ} \mathrm{C}\right.$ or $\left.660^{\circ} \mathrm{F}\right)$. The decomposition products retain the original mineral value of the nahcolite and can still be recovered by solution mining following retorting. The increased $\mathrm{CO}_{2}$ released dung oil shale production, however, along with the additional energy the nahcolite decomposition reaction consumes, may make oil shale retorting prior to nahcolite extraction less viable due to potentially higher energy costs and concerns over $\mathrm{CO}_{2}$ emissions. In some instances, reclamation requirements and water-use restrictions for dual oil shale-nahcolite recovery operations may require that postretorting water flushing and solution mining of the sodium minerals be conducted simultaneously, despite $\mathrm{CO}_{2}$ concerns.

The significant porosity and groundwater movement within the eached interval also complicates mining or implementation of the down-hole heater systems currently being developed for in situ oil shale retorting. The leached interval contains the upper and lower Piceance Basin aquifer systems (Weeks and ohl groundwater resources separated by the Mahogany zone. Therefore,

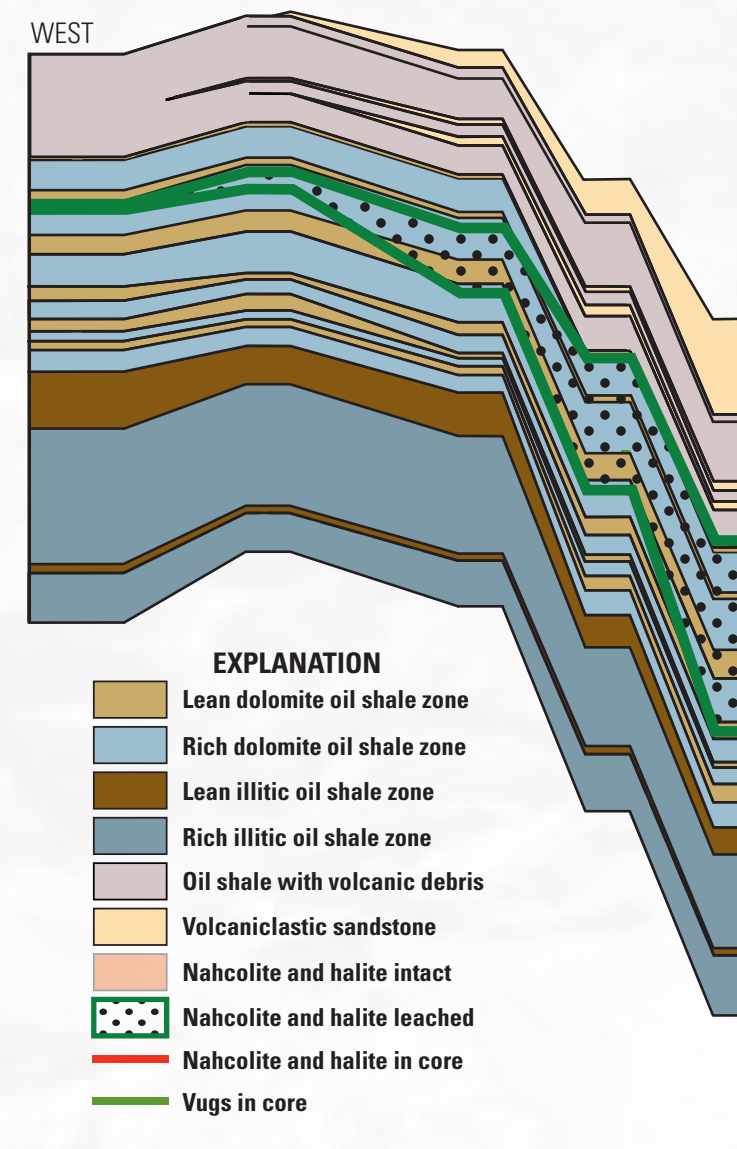

Figure 3. Detailed cross section showing the "rich" and "lean" oil shale zones, major mineralogical facies, and extents of observed nahcolite and nahcoltevigs in core samples of the Piceance Basin, Colorado.

shale zones within the leached interval (fig. 1, principally R-5 and R-6 zones) will require preservation of water quality Re these aquifers. It is also undesirable to use down-hole 作 additional energy is required to achieve retorting temperatures. To address this issue, freeze-wall technology has been tested a pilotscale for use in isolating in situ retorts duning oil operators to pump groundwater out of the retort site, isolating
oforing

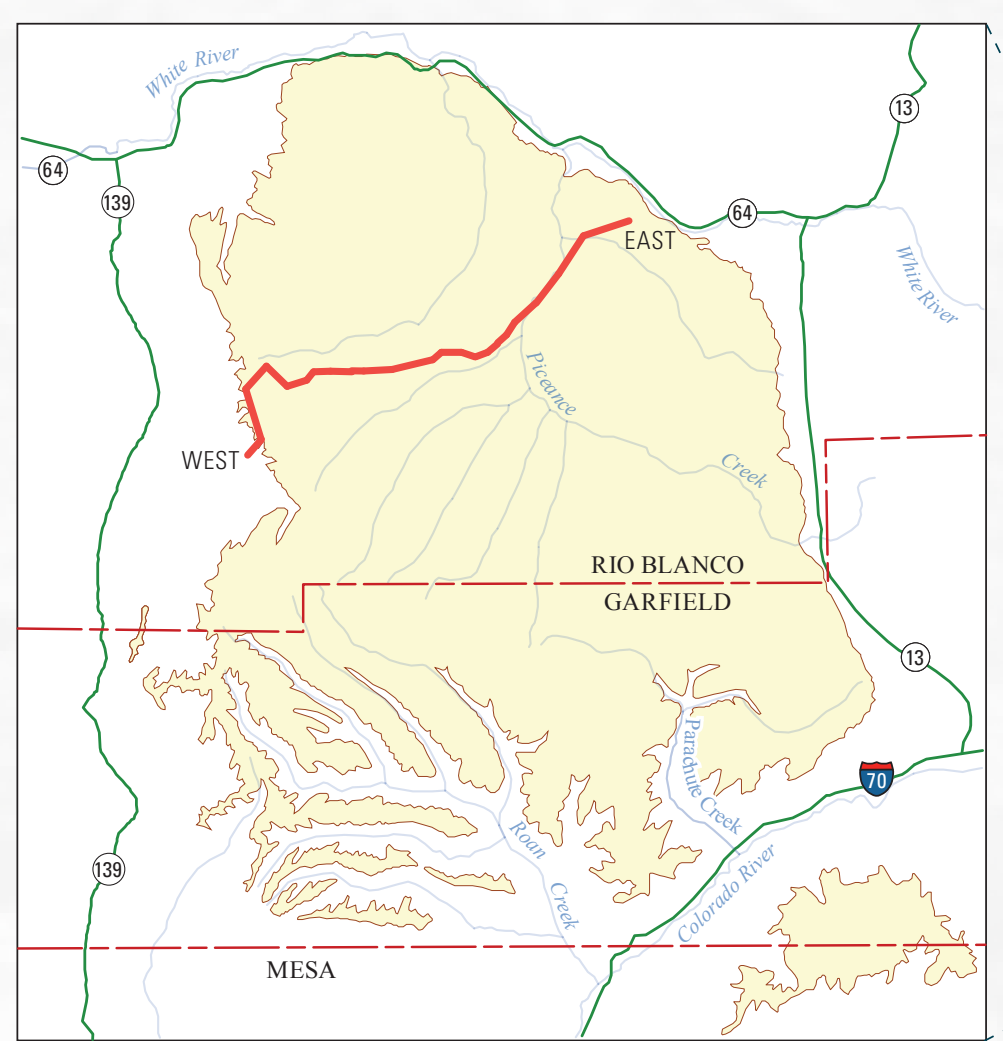

\section{Structural Cross Section}
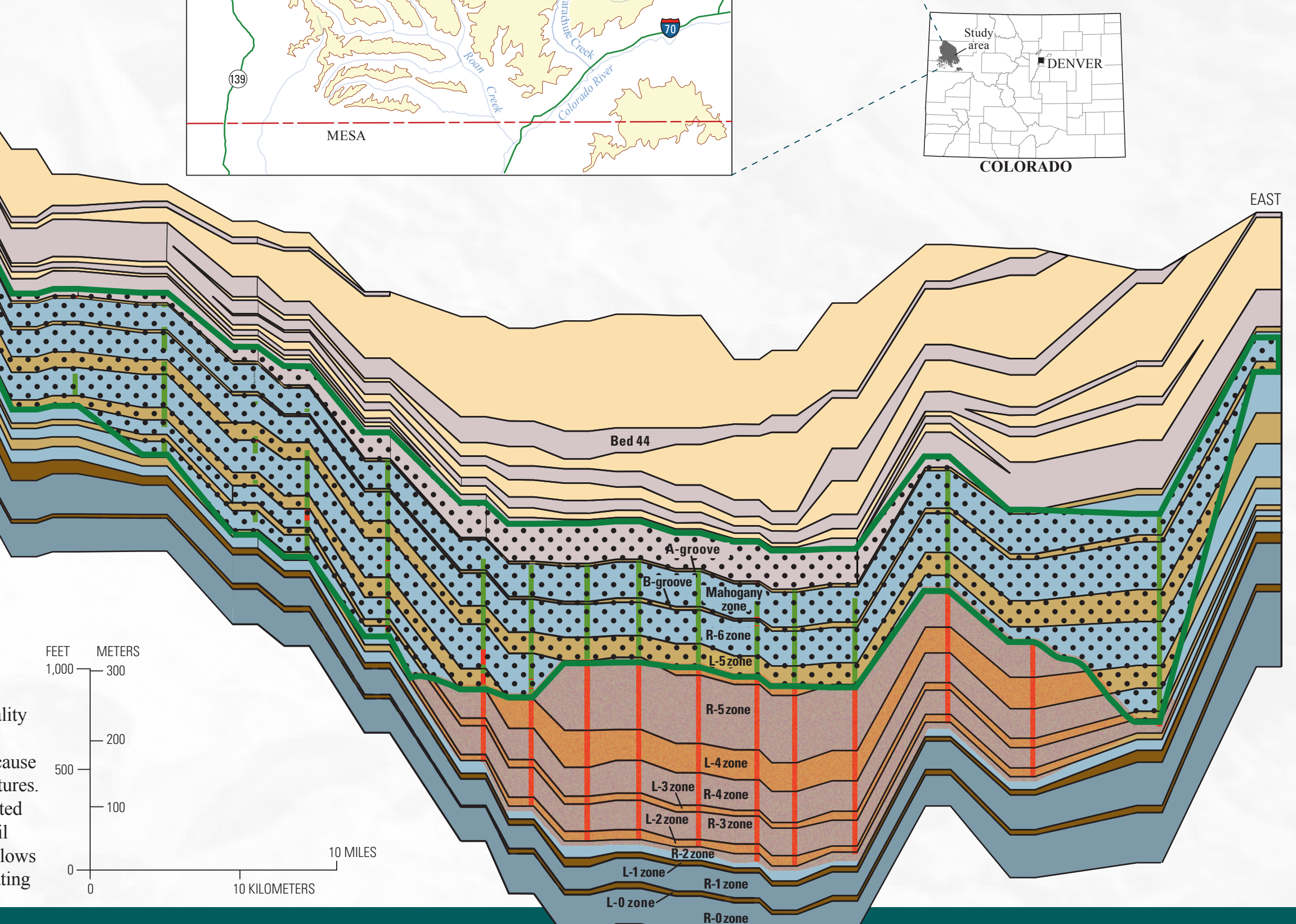

10 KLLMETERS 
Table 1. Oil shale resources in stratigraphic-mineralogical intervals in the Green River Formation, Piceance Basin, Colorado.

[Resource figures are in billions of barrels; --, no oil found]

\begin{tabular}{|c|c|c|c|c|c|}
\hline & \multirow{2}{*}{$\begin{array}{l}\text { Total resource } \\
\text { in place }\end{array}$} & \multicolumn{2}{|c|}{$\begin{array}{c}\text { Oil yield of } \\
15 \text { gallons per ton (GPT) } \\
\text { or greater }\end{array}$} & \multicolumn{2}{|c|}{$\begin{array}{c}\text { Oil yield of } \\
25 \text { gallons per ton (GPT) } \\
\text { or greater }\end{array}$} \\
\hline & & Oil in place & $\begin{array}{c}\text { As percent of } \\
\text { total in place } \\
>15 \mathrm{GPT} \\
\end{array}$ & Oil in place & $\begin{array}{c}\text { As percent of } \\
\text { total in place } \\
>25 \mathrm{GPT} \\
\end{array}$ \\
\hline Garden Gulch Member (illitic interval) & 302.2 & 99.7 & 10.8 & 11 & 3.1 \\
\hline Parachute Creek Member (non-saline R-2 zone) & 54.3 & 35.7 & 3.9 & 15.9 & 4.5 \\
\hline Parachute Creek Member (saline-mineral interval) & 203.2 & 197.6 & 21.5 & 128.6 & 36.6 \\
\hline Parachute Creek Member (leached interval) ${ }^{1}$ & 359 & 269.4 & 29.3 & 84.2 & 23.9 \\
\hline Parachute Creek Member Mahogany zone (leached) & 159 & 156 & 17 & 105 & 29.9 \\
\hline Parachute Creek Member bed 44 (leached) & 185.6 & 91.5 & 9.9 & -- & -- \\
\hline Parachute Creek Member marginal oil shales ${ }^{2}$ & 257.8 & 70.4 & 7.6 & 7 & 2 \\
\hline Total Piceance Basin ${ }^{3}$ & 1,525 & 920 & 60 & 352 & 23 \\
\hline
\end{tabular}

${ }^{1}$ Does not include the leached portions of the Mahogany zone or bed 44

${ }^{2}$ Indicates low-grade shales deposited at the basin margins.

${ }^{3}$ Johnson and others, 2010. Minor discrepancies in sums and percentages shown may arise due to rounding errors.

it from groundwater flow during oil shale heating and oil production. This approach is energy-intensive and operationally complicated, but it is also robust and fully reversible, unlike other methods of isolating in situ retorts such as grouting or hydraulic bypass.

In situ development of the Garden Gulch Member is also being studied by RD\&D lease holders. Because the illitic interval does not contain nahcolite or protected groundwater resources and is effectively sealed by the overlying saline-mineral interval, retorting can be conducted without isolating the site and without additional treatment to solution-mine saline minerals or to remediate spent shale following heating (Burnham and others, 2010). Although this simplifies the development approach, the greater depth of this interval, typically between 2,000 and 2,200 feet below the surface in the basin center, may complicate heating operations.

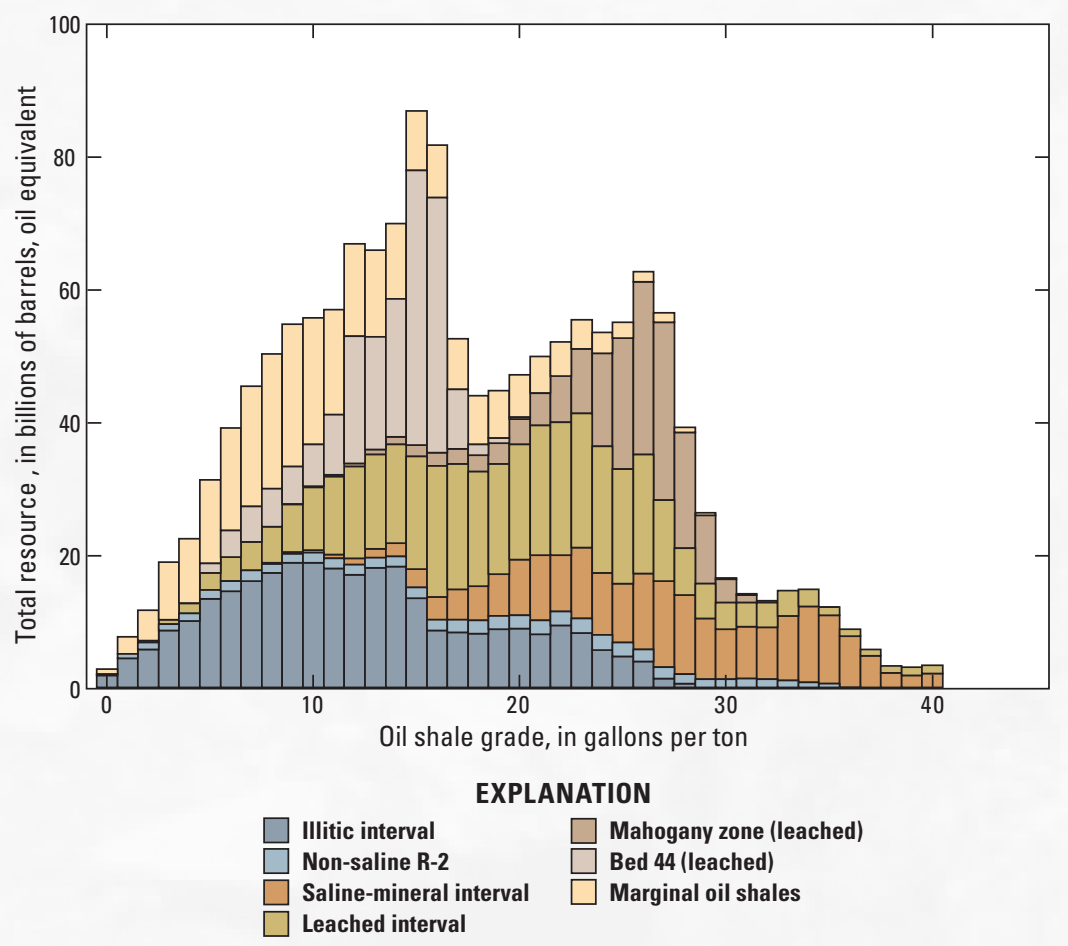

Table 1 lists the amount of in-place oil in the defined intervals, including total oil in oil shale grades $\geq 15$ GPT and $\geq 25$ GPT. Of the total in-place oil (1.525 trillion barrels), 203.2 billion barrels (13.3 percent) are associated with the saline-mineral interval and 703.6 billion barrels (46.1 percent) are present in the leached interval (including the Mahogany zone and bed 44). The illitic shales contain 302.2 billion barrels (19.8 percent). Figure 4 shows a histogram summarizing the total distribution of the Piceance Basin oil shale resource according to grade (Birdwell and others, 2013) and how the resource is distributed within the major stratigraphic-mineralogical intervals. The non-saline lower R-2 zone, Mahogany zone, and bed 44 intervals (fig. 1) are plotted separately from the leached interval on the distribution plot.

Figure 4. Oil shale resource in-place distribution plot for the Piceance Basin, Colorado. The stacked bars represent the in-place oil resource for each stratigraphic-mineralogical interval in the basin for a particular grade.

Each of the major oil shale intervals within the Piceance Basin contain resource with high development potential but also has unique challenges related to resource recovery. The analysis presented here highlights the association between saline minerals and high-grade oil shale in the Piceance Basin. The majority of the high-grade oil shale resource in the Piceance Basin, 128.6 billion barrels (36.6 percent of the total $\geq 25$ GPT), and most of the richest oil shales in the basin ( $\geq 30$ GPT) (fig. 4) are concentrated in the saline-mineral interval. This has important implications, both for understanding the geological setting of Eocene Lake Uinta and facilitating the development of Piceance Basin oil shale resources. 


\section{Methods}

Oil shale grade is determined by the Fischer assay method, which is used to measure oil yield under a particular set of pyrolysis conditions (American Society for Testing and Materials, 1980). Data summarizing Fischer assay analyses conducted on Piceance Basin oil shale samples are available as part of the most recent USGS assessment report (U.S. Geological Survey Oil Shale Assessment Team, 2010).

The oil shale interval in the Piceance Basin is subdivided into 17 stratigraphically defined "rich" and "lean" zones, 13 of which contain or once contained saline minerals (fig. 1) (Donnell and Blair, 1970; Cashion and Donnell, 1972). The extent of the saline-mineral area for each of the 13 zones was modified from Brownfield and others (2010), and the extent of saline-mineral leaching was determined using core descriptions and x-ray diffraction analysis (figs. 2 and 3). After the extents of the saline mineral and leached intervals were defined, oil shale resource data (U.S. Geological Survey Oil Shale Assessment Team, 2010) were incorporated using geographic information systems (GIS) technology to determine how much in-place oil was present in the 17 (4 illitic, 13 saline mineral and leached) oil shale zones (fig. 1) on a per-acre basis, then separated and summed for the intervals of interest. The non-saline portion of the R-2 zone was considered

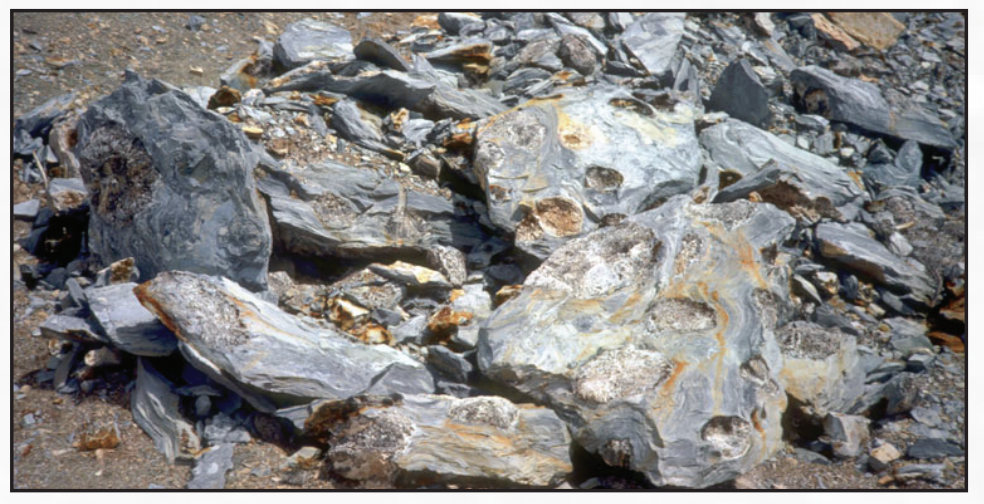

\section{Nahcolite nodules or aggregates from the R-5 oil shale zone (see fig. 1) in the Green River Formation, Piceance Basin. Photograph taken at the Superior quarry in Rio Blanco County, Colorado.}

separately, while the upper portion of R-2 that contains nahcolite was included with the saline-mineral interval. A zonal statistics function was used to develop the histograms (fig. 4) relating oil shale grade (GPT) to total oil yield (barrels of oil) for each interval and selected zones. The resolution of the analysis is constrained by the data density and stratigraphic resolution.

\section{References Cited}

American Society for Testing and Materials, 1980, ASTM D3904-90 Test method for oil from oil shale (resource evaluation by the Fischer assay procedure): West Conshohocken, Penn., Annual Book of ASTM Standards [withdrawn 1996].

Birdwell, J.E., Mercier, T.J., Johnson, R.C., and Brownfield, M.E., 2013, In-place oil shale resources examined by grade in the major basins of the Green River Formation, Colorado, Utah, and Wyoming: U.S. Geological Survey Fact Sheet 2012-3145, 4 p.

Boak, Jeremy, 2011, Carbon dioxide emissions and water consumption from oil shale production-A second look, in Boak, Jeremy, and Birdwell, J.E., eds., Proceedings of the 30th Oil Shale Symposium, October 18-20, 2013, Golden, Colo.: Colorado School of Mines, 19 p.

Brownfield, M.E., Mercier, T.J., Johnson, R.C., and Self, J.G., 2010, Nahcolite resources in the Green River Formation, Piceance Creek Basin, Colorado, chap. 2 of Oil shale and nahcolite resources of the Piceance Basin, Colorado: U.S. Geological Survey Digital Data Series 69-Y, 57 p.

Burnham, A.K., Day, R.L., Hardy, M.P., and Wallman, P.H., 2010, AMSO’s novel approach to in-situ oil shale recovery, in Ogunsola, O.I., Hartstein, A.M., and Ogunsola, O., eds., Oil shale - A solution to the liquid fuel dilemma: Washington, D.C., American Chemical Society, p. 149-160.

Cashion, W.B., and Donnell, J.R., 1972, Chart showing correlation of selected key units in the organic-rich sequence of the Green River Formation, Piceance Creek Basin, Colorado, and Uinta Basin, Utah: U.S. Geological Survey Oil and Gas Investigations Chart OC-65.

Donnell, J.R., and Blair, R.W., Jr., 1970, Resource appraisal of three rich oil shale zones in the Green River Formation, Piceance Creek Basin, Colorado: Colorado School of Mines Quarterly, v. 65, no. 4, p. 73-87.
Johnson, R.C., Mercier, T.J., Brownfield, M.E., Pantea, M.P., and Self, J.G., 2010, An assessment of in-place oil shale resources in the Green River Formation, Piceance Basin, Colorado, chap. 1 of Oil shale and nahcolite resources of the Piceance Basin, Colorado: U.S. Geological Survey Digital Data Series 69-Y, 187 p.

Mercier, T.J., Johnson, R.C., Brownfield, M.E., and Self, J.G., 2010, Inplace oil shale resources underlying Federal lands in the Piceance Basin, western Colorado: U.S. Geological Survey Fact Sheet 2010-3041, 4 p.

U.S. Geological Survey Oil Shale Assessment Team, 2010, Oil shale and nahcolite resources of the Piceance Basin, Colorado: U.S. Geological Survey Digital Data Series 69-Y, [variously paged].

Weeks, J.B., Leavesley, G.H., Welder, F.A., and Saulnier, G.J., Jr., 1974, Simulated effects of oil-shale development on the hydrology of the Piceance Basin, Colorado: U.S. Geological Survey Professional Paper 908, 84 p.

-By Justin E. Birdwell, Tracey J. Mercier, Ronald C. Johnson, Michael E. Brownfield, and John D. Dietrich

For additional information contact:

Director, Central Energy Resources Science Center

U.S. Geological Survey

Box 25046, MS 939

Denver Federal Center

Denver, C0 80225-0046

http://energy.usgs.gov

ISSN 2327-6916 (print) ISSN 2327-6932 (online) http://dx.doi.org/10.3133/ss20133115 